\title{
Column adsorption of Violet Crystal and Methyl Red by deactivated lichen Parmotrema dilatatum
}

\author{
Kouassi Kouadio Dobi-Brice, Ekou Lynda, Yacouba Zoungranan, Koffi Kouamé Sévariste, Ekou Tchirioua \\ ${ }^{1}$ Department of Chemistry, University of Nangui Abrogoua(LTPCM), 02 Bp 801 Abidjan 02, Ivory Cost
}

Correspondence Author: Lynda Ekou, Department of Chemistry, University of Nangui Abrogoua (LTPCM), 02 Bp 801 Abidjan 02, Ivory Cost E-mail: ekou_lynda@yahoo.fr

Received date: 18 March 2019, Accepted date: 5 May, Online date: 25 May 2019

Copyright: () 2019 Kouassi Kouadio Dobi-Briceet al., This is an open-access article distributed under the terms of the Creative Commons Attribution License, which permits unrestricted use, distribution, and reproduction in any medium, provided the original author and source are credited.

\begin{abstract}
In recent decades, there is an increase industrial sector in Ivory Coast, which results in the establishment of textile, agrochemical, pharmaceutical, etc. These industries release toxic chemicals such as dyes (Bhuiyan et al., 2017) into aquatic systems. Rejected dyes may cause gastrointestinal infections in humans with nausea, vomiting and diarrhea (Dulce et al., 2017; Jabs and Drutz, 2001). In plants, they affect negatively the process of photosynthesis (Tahir et al., 2016).

Several effluent treatment methods (Lofrano et al., 2016) exist but remain expensive and inaccessible for developing countries such as Every coast. Adsorption is an alternative to these problems.

The objective of these studies is to remove two dyes, Violet Crystal (VC) and Methyl Red (MR), on deactivated lichens using an adsorption column.

The volume flow rate, lichen grain size, adsorption bed height and initial column entry concentration will be evaluated.

Column adsorption tests have shown that feed rate, lichen grain diameter, adsorption bed height and dye concentration are parameters that influence the adsorption capacity and operating times of the column, such as residence and saturation times. The best residence and saturation times, and the best adsorption capacities were observed with a low flow rate $D=0.07 \mathrm{~L} / \mathrm{min}$, a high bed height $\mathrm{h}=8 \mathrm{~cm}$ corresponding to a mass of $100 \mathrm{~g}$, a small size of lichen grain [125-250 $\mu \mathrm{m}]$. However, the increase in dye concentration has resulted in a decrease in residence and saturation times and an increase in the amount of adsorbed dye.
\end{abstract}

Keywords: Deactivated lichens, Violet Crystal and Methyl Red, adsorption column

\section{INTRODUCTION}

Contamination of aquatic environments by synthetic organic pollutants from the textile, agrochemical, plastics, pharmaceutical and petrochemical industries is widespread in most developing countries such as Ivory Coast, where regulation standards for pollution are relatively flexible. These pollutants are thus released into the environment without being treated. Textile industries effluents contain chemical products that are potentially harmful, structurally diverse, toxic, carcinogenic, or mutagenic chemicals and therefore present real risks for the environment and human (Croce et al., 2017).

Violet Crystal (VC) and Methyl Red (MR) are two dyestuffs widely used in the dyeing industry and fall within this toxicity range.

Most methods (electrochemical oxidation (Nidheesh et al., 2018), ozonation (Wijannarong et al., 2013), electrocoagulation (Pirkarami and Olya, 2017), photo Fenton process (Sohrabi et al., 2017), nanofiltration, reverse osmosis (Nataraj et al., 2009)) used to treat wastewater containing dyes often generate toxic by-products and remain very expensive and therefore inaccessible in poor or developing countries. The technique of adsorbing pollutants on natural supports such as sawdust (Dulman and Cucu-Man, 2009), activated carbon (Baysal et al., 2018), clay (Kausar et al., 2018), groundnut shell (Liu et al., 2018), nanofibre membranes (Mousavi et al., 2018), alumina and silica (Kannan et al., 2008), banana peel (Munagapati et al., 2018), orange peels (Arami et al., 2005) are considered as an alternative solution to these problems.

Lichen is a living composite organism that results from a symbiotic, mutualistic and stable self-supporting association of a heterotrophic fungus, called mycosymbiote or mycobiont and an autotrophic alga, called photosymbiotic or also photobiont. 
Many studies have shown a wide use of lichens as indicators of environmental quality (Ekou et al., 2017; Zoungranan et al., 2018) due to their high retention and accumulation capacity of several types of pollutants. These plants are also used as carriers in metal and dyes adsorption processes (Ekou et al., 2017) (Dobi-Brice et al., 2018a, 2018b) The adsorption columns are very useful in pollution control and can be sized according to the desired performance.

In the column, VC and MR adsorption tests on deactivated lichens were performed by evaluating some parameters such as feed rate, lichen grain diameter, adsorption bed height, and dye concentration.

\section{MATERIALS AND METHODS}

\subsection{Sampling}

Lichen thalli Parmotrema dilatatum is collected from the forest reserve of the LAMTO ecology station $\left(5.02^{\circ} \mathrm{C}\right.$ West and $6.13^{\circ} \mathrm{C}$ North). This reserve is located $174 \mathrm{~km}$ from the city of Abidjan (Every coast) on the Abidjan-Yamoussokro road, between Singrobo and Taabo, and extends along the Bandama River. This area is a 2500 ha natural park, with a tropical climate. The average temperature per year is $28.28^{\circ} \mathrm{C}$. The annual rainfall value is $1194 \mathrm{~mm}$, with a humidity level above $58 \%$.

\subsection{Deactivation and crushing of lichens}

In the laboratory, lichens are detached from their substrates and then cleaned manually to remove soil, leaf, dust, or insect debris. The thalli are then washed with distilled water. An appropriate amount of lichens is placed in the oven at $80^{\circ} \mathrm{C}$ for 48 hours to deactivate them. Deactivated lichens are crushed sieved.

\subsection{Preparation of dyes}

Solutions of $500 \mathrm{mg} / \mathrm{L}$ of $\mathrm{VC}$ dye $(\mathrm{C} 25 \mathrm{H} 30 \mathrm{~N} 3 \mathrm{Cl}$, C.I. 42555 , molecular weight $=407.99 \mathrm{~g} / \mathrm{mol}$, max $=582 \mathrm{~nm})$, and $\mathrm{MR}$ $(\mathrm{C} 15 \mathrm{H} 15 \mathrm{~N} 3 \mathrm{O} 2$, C.I. 13020 , molecular weight $=269.3 \mathrm{~g} / \mathrm{mol}, \max =436 \mathrm{~nm})$ were prepared. We diluted the initial solutions in order to obtain diluted solutions.

The chemical structures of the dyes are given in Figure 1.

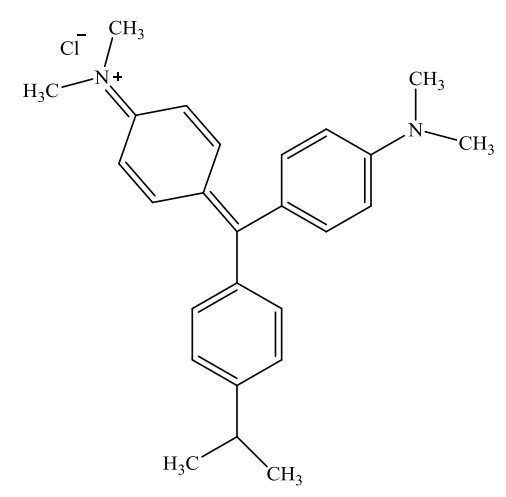

(a)

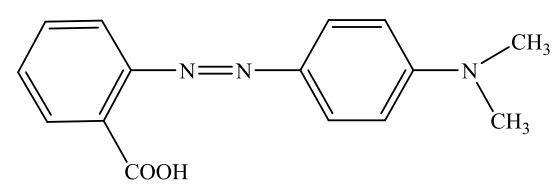

(b)

Figure 1: Chemical structures of the CV (a) and MR (b)

\subsection{Experimental set-up}

The experimental device includes a glass column $22 \mathrm{~cm}$ long and $8 \mathrm{~cm}$ inside diameter, a container with adjustable valve flow rate, a pump for the circulation of the solution, filter paper, biomass' bed and a container for recovering the treated solution.

The optical density of the treated solution is read using a UV/visible spectrophotometer (WFJ-752, Beijing China).

\subsection{Biosorption Studies}

The column feed rate varies from 0.07 to $0.21 \mathrm{~L} / \mathrm{min}$ by step of 0.07 . The lichen grain size effect was performed using the following grain size ranges:

$[125-250 \mu \mathrm{m}],[250-500 \mu \mathrm{m}]$ and $[500-800 \mu \mathrm{m}]$. As for the influence of the height of the adsorption bed, this was achieved by varying the mass of lichen from 20 to $100 \mathrm{~g}$ by step of 20 . The initial dye concentration effect was studied from 10 to $30 \mathrm{mg} / \mathrm{L}$.

The quantity of biosorbed dye per gram of lichen at equilibrium $Q_{a d s}(\mathrm{mg} / \mathrm{g})$ was calculated using the following relationship (Adrián Bonilla-Petriciolet; Didilia Ileana Mendoza-Castillo; Hilda Elizabeth Reynel-Ávila, 2017): 
Citation: Kouassi Kouadio Dobi-Brice, et al., Column adsorption of Violet Crystal and Methyl Red by deactivated lichen Parmotrema dilatatum. Australian Journal of Basic and Applied Sciences, 13(5): 26-34. DOI: 10.22587/ajbas.2019.13.5.3

$$
Q_{a d s}=\frac{\left(C_{o}-C_{t}\right) D * t_{\text {total }}}{m}
$$

Where Co $(\mathrm{mg} / \mathrm{L})$ is the initial concentration of the dye, $\mathrm{C}_{\mathrm{t}}(\mathrm{mg} / \mathrm{L})$ the saturation concentration, $\mathrm{D}$ the feed rate $(\mathrm{L} / \mathrm{min})$, $\mathrm{t}_{\text {total }}$ the saturation time and $\mathrm{m}$ the mass expressed in $\mathrm{mg}$ of lichens.

\subsection{Statistical analysis}

All calculation was performed with Microsoft office Excel 2013 Professional (Microsoft Corporation, WA, USA). Mean values were determined from three individual measurements.

\section{RESULTS AND DISCUSSIONS}

The influences of the different parameters on the adsorption process of the VC and RM were examined by plotting the ratio of residual dye concentration to initial $C_{t} / C_{0}$ concentration as a function of time, i.e. $\frac{C_{t}}{C_{o}}=f(t)$

\subsection{Effect of flow}

The results of the filtration rate study are presented in Figure 2 and Figure 3.

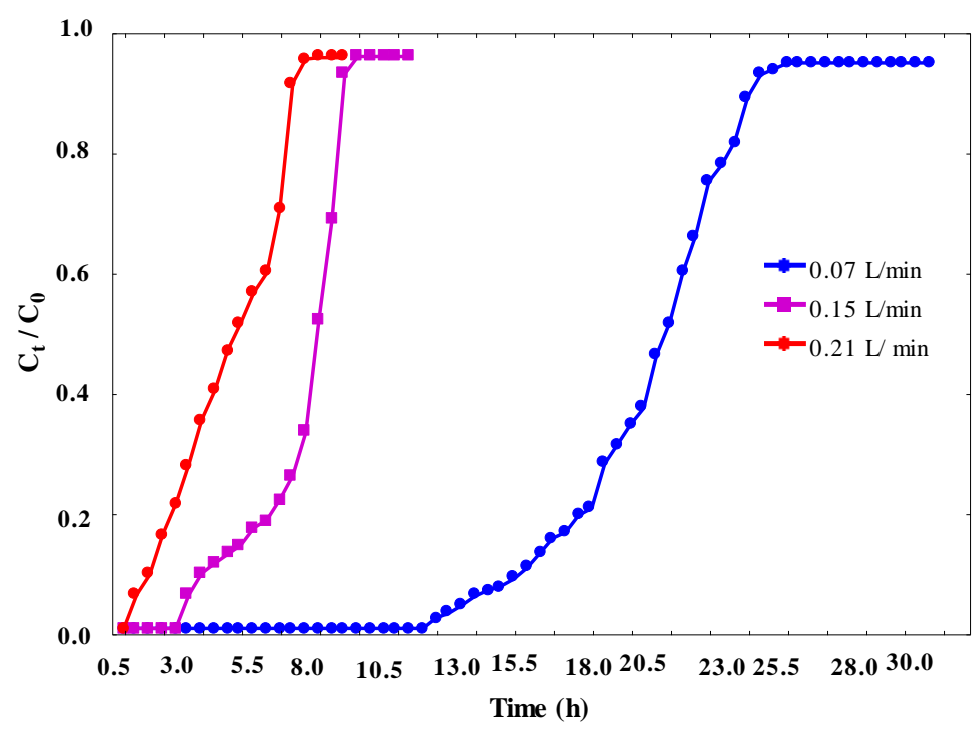

Figure 2: Breakthrough curve for studying the influence of the $\mathrm{VC}$ feed rate: $\left(\mathrm{m}=60 \mathrm{~g}, \mathrm{Co}=10 \mathrm{mg} / \mathrm{g}, \mathrm{H}=4 \mathrm{~cm}, \mathrm{~T}=25 \mathrm{C}{ }^{\circ}\right.$, each point on the graph represents an average which was determined from three individuals measurements.).

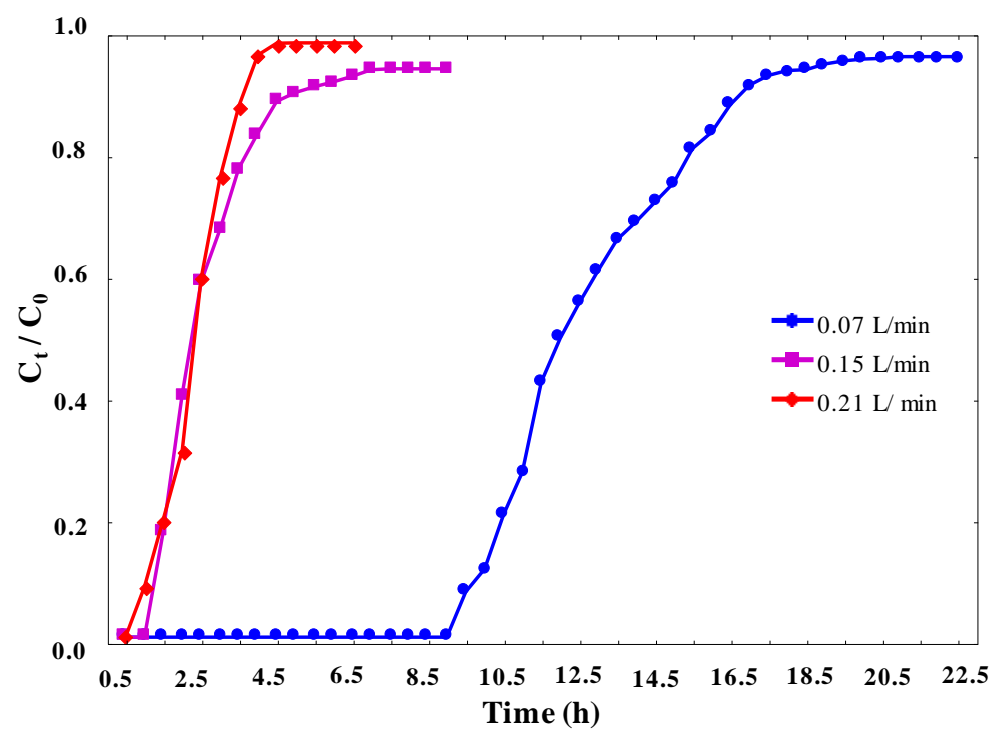

Figure 3: Breakthrough curve for studying the influence of the $\mathrm{MR}$ feed rate $\left(\mathrm{m}=60 \mathrm{~g}, \mathrm{Co}=10 \mathrm{mg} / \mathrm{g}, \mathrm{H}=4 \mathrm{~cm}, \mathrm{~T}=25 \mathrm{C}{ }^{\circ}\right.$, each point on the graph represents an average which was determined from three individuals measurements.). 
Citation: Kouassi Kouadio Dobi-Brice, et al., Column adsorption of Violet Crystal and Methyl Red by deactivated lichen Parmotrema dilatatum. Australian Journal of Basic and Applied Sciences, 13(5): 26-34. DOI: 10.22587/ajbas.2019.13.5.3

The experimental values obtained from the breakthrough curves for the influence of the CV and RM solution flow rate are presented in the table below.

Table. 1: Experimental values for the effect of the VC and MR feed rate in contact with disabled lichen ParmotremaDilatatum

\begin{tabular}{|c|c|c|c|c|c|c|}
\hline & \multicolumn{6}{|c|}{ Parameters } \\
\hline dye & $\begin{array}{l}\text { Mass } \\
\mathrm{m}(\mathrm{g})\end{array}$ & $\begin{array}{l}\text { Concentration Co } \\
(\mathrm{mg} / \mathrm{L})\end{array}$ & $\begin{array}{l}\text { Flow rate } \\
\mathrm{D}(\mathrm{L} / \mathrm{min})\end{array}$ & $\begin{array}{l}\text { Residence time } \\
\text { (h) }\end{array}$ & $\begin{array}{l}\text { Saturation time } \\
\text { (h) }\end{array}$ & $\begin{array}{l}\text { Adsorbed quantity } \\
(\mathrm{mg} / \mathrm{g})\end{array}$ \\
\hline \multirow{3}{*}{$\mathrm{VC}$} & \multirow{3}{*}{60} & \multirow{3}{*}{10} & 0.07 & 13 & 22.5 & 14.27 \\
\hline & & & 0.15 & 3 & 7.5 & 10.18 \\
\hline & & & 0.21 & 1 & 4.5 & 8.54 \\
\hline \multirow{3}{*}{ MR } & \multirow{3}{*}{60} & \multirow{3}{*}{10} & 0.07 & 9.5 & 14 & 8.87 \\
\hline & & & 0.15 & 1.5 & 3.5 & 4.75 \\
\hline & & & 0.21 & 0.5 & 2 & 3.79 \\
\hline
\end{tabular}

The experimental data in Table I show that the operating times of the column, such as residence time and saturation time decrease when the feed rate increases. In the case of the $\mathrm{VC}$, the obtained residence times are $13 \mathrm{~h}$, three $\mathrm{h}$, and one $\mathrm{h}$ corresponding respectively to the flow rates $0.07,0.15$, and $0.21 \mathrm{~L} / \mathrm{min}$. At this same flow rate, the saturation of the adsorption bed is observed at following times 22 h $30 \mathrm{~min}$, seven h $30 \mathrm{~min}$ and four h $30 \mathrm{~min}$ respectively. As for the MR, the residence time increases from $9 \mathrm{~h}$ $30 \mathrm{~min}$ to $30 \mathrm{~min}$ when the flow rate increases respectively from 0.07 to $0.21 \mathrm{~L} / \mathrm{min}$. These results could be explained by the fact that the filtration rate influences the contact time of the elemental volume portion $\mathrm{dv}$ of the effluent to be treated with the elemental number of active sites of the adsorbent bed. Therefore, the adsorption capacity decreases from 14.27 to $8.54 \mathrm{mg} / \mathrm{g}$ for the VC and from 8.87 to $3.79 \mathrm{mg} / \mathrm{g}$ for the MR when the flow rate increases. Several authors have also suggested that: (i) the adsorption of a solute on a solid support is done in two steps: First according to a surface fixation and then diffusion through the inner layers of the support; and (ii) the limiting factor is the contact time between the two phases (liquid and solid) which could limit the kinetics of the reaction. A similar trend has been reported by Vieira et al (2018). These authors studied the adsorption of azo dyes in a fixed-bed column filled with chitosan-coated glass beads at different degrees of deacetylation, at different flow rates ranging from 3 to $5 \mathrm{~mL} / \mathrm{min}$. They found that the maximum capacity of the column was $75.5 \mathrm{mg} / \mathrm{g}$ with the lowest flow rate of 3 $\mathrm{mL} / \mathrm{min}$.

Considering the best results obtained with the lowest flow rate $(0.07 \mathrm{~L} / \mathrm{min})$, this value was fixed in the for the study of other parameters.

\subsection{Grain size effect}

The particle diameter of an adsorbent is an important parameter for the characterization of this carrier. Figures 4 and Figure 5 show the changes in the operating times of the column as a function of the different sizes of lichen grain.

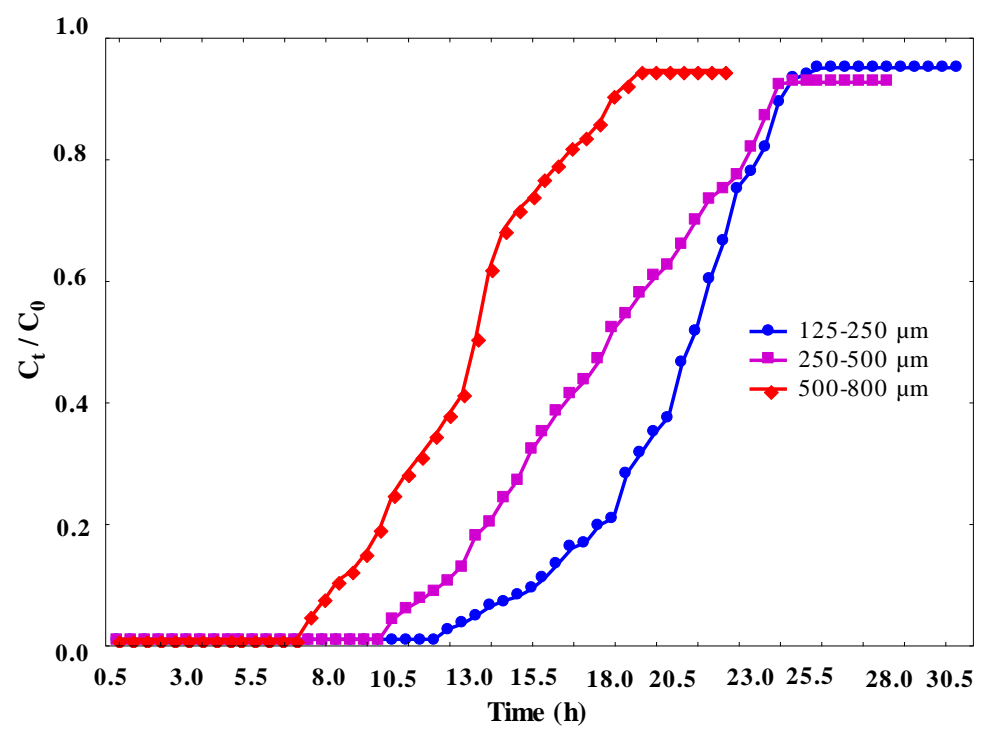

Figure 4: Breakthrough curve for studying the influence of the granulometry of the adsorbent on VC adsorption $(\mathrm{D}=0.15 \mathrm{~L} / \mathrm{min}$, $\mathrm{m}=60 \mathrm{~g}, \mathrm{Co}=10 \mathrm{mg} / \mathrm{g}, \mathrm{H}=4 \mathrm{~cm}, \mathrm{~T}=25 \mathrm{C}^{\circ}$, each point on the graph represents an average which was determined from three individuals measurements.). 


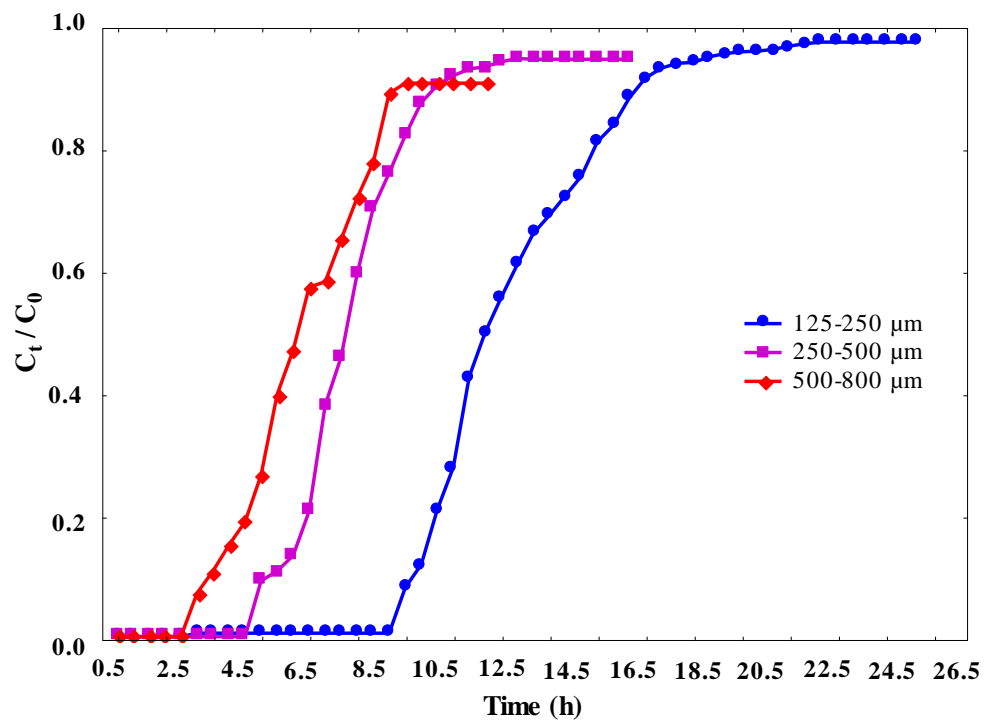

Figure 5: Breakthrough curve for studying the influence of the granulometry of the adsorbent on MR adsorption (D=0.15 L/min, $\mathrm{m}=60 \mathrm{~g}, \mathrm{Co}=10 \mathrm{mg} / \mathrm{g}, \mathrm{H}=4 \mathrm{~cm}, \mathrm{~T}=25 \mathrm{C}^{\circ}$, each point on graph represents an average which was determined from three individuals measurements.).

The experimental values obtained from the breakthrough curves for the influence of lichen grain size on VC and MR adsorption are presented in the table below.

Table II: Experimental values relating to the influence of the granulometry of the adsorbent.

\begin{tabular}{|c|c|c|c|c|c|c|}
\hline & \multicolumn{6}{|c|}{ Parameters } \\
\hline dye & $\begin{array}{l}\text { Mass } \\
\mathrm{m}(\mathrm{g})\end{array}$ & $\begin{array}{l}\text { Flow rate } \\
\mathrm{D}(\mathrm{L} / \mathrm{min})\end{array}$ & Granulometry $(\mu \mathrm{m})$ & $\begin{array}{l}\text { Residence time } \\
\text { (h) }\end{array}$ & Saturation time (h) & $\begin{array}{l}\text { Adsorbed } \\
\text { quantity }(\mathrm{mg} / \mathrm{g})\end{array}$ \\
\hline \multirow{3}{*}{ VC } & \multirow{3}{*}{60} & \multirow{3}{*}{0.07} & $125-250$ & 13 & 22.5 & 14.27 \\
\hline & & & $250-500$ & 10.5 & 21 & 13.35 \\
\hline & & & $500-800$ & 7.5 & 15.5 & 9.83 \\
\hline \multirow{3}{*}{ MR } & \multirow{3}{*}{60} & \multirow{3}{*}{0.07} & $125-250$ & 9.5 & 14 & 8.87 \\
\hline & & & $250-500$ & 5 & 13.5 & 8.56 \\
\hline & & & $500-800$ & 3 & 10.5 & 6.68 \\
\hline
\end{tabular}

From these results, it appears that the grain size of lichens influences residence and saturation times, and therefore the amount of adsorbed dye. For the VC, the residence time is $13 \mathrm{~h}$, ten h $30 \mathrm{~min}$ and seven h $30 \mathrm{~min}$ respectively for granulometries $125-250$, 250-500 and 500-800 $\mu \mathrm{m}$. For MR, we obtain nine $\mathrm{h} 30 \mathrm{~min}$, five $\mathrm{h}$ and three $\mathrm{h}$ for the same grain diameters respectively. As grain size increases, retention time decreases. This result is similar to the saturation time of the column which falls from $22 \mathrm{~h} 30 \mathrm{~min}$ to $15 \mathrm{~h} 30 \mathrm{~h}$ min for the VC and from $14 \mathrm{~h}$ to $10 \mathrm{~h} 30 \mathrm{~min}$ for the MR. The decrease in these column operating times is accompanied by a decrease in the amount of dye retained by the adsorption bed. These results could be justified by the fact that the smaller grain diameters form a low-permeable bed, which favors a large specific exchange surface. This large specific exchange surface increases the contact time between the dye and lichen, improves the adsorption rate and therefore promotes the absorbency (Nussbaum, 2008) of lichens. In other words, an exchange surface made up of small grains is characterized by the presence of narrower pores in its matrix. This characteristic may be sufficient to explain the differences observed in the transport of dyes between the three types of grain diameters. The "straining" mechanism corresponds to the trapping of colloids as they pass through pores that are too narrow (Auset and Keller, 2006; Jeremy et al., 2004). In the interval 125-250 $\mu$ m, it is possible for "straining" to be more important, which explains why dyes are more retained in this interval than in the others. The results of this study are in agreement with those of Fabian Nussbaum's (2008) work on the development of a pilot-scale biosorption facility. This author showed that in column adsorption, algae beads with a diameter of $3.20 \mathrm{~mm}$ adsorb copper more quickly than algae beads with a diameter of $4.62 \mathrm{~mm}$. Aurélien Desaunay (2011) also observed that Fontainebleau's grains of sand, which are smaller than those of Hostun sand, have a better capacity to retain pollutants.

\subsection{Effect of mass or height of the bed}

The breakthrough curves for studying the influence of adsorbent mass are shown in Figure 6 and Figure 7 


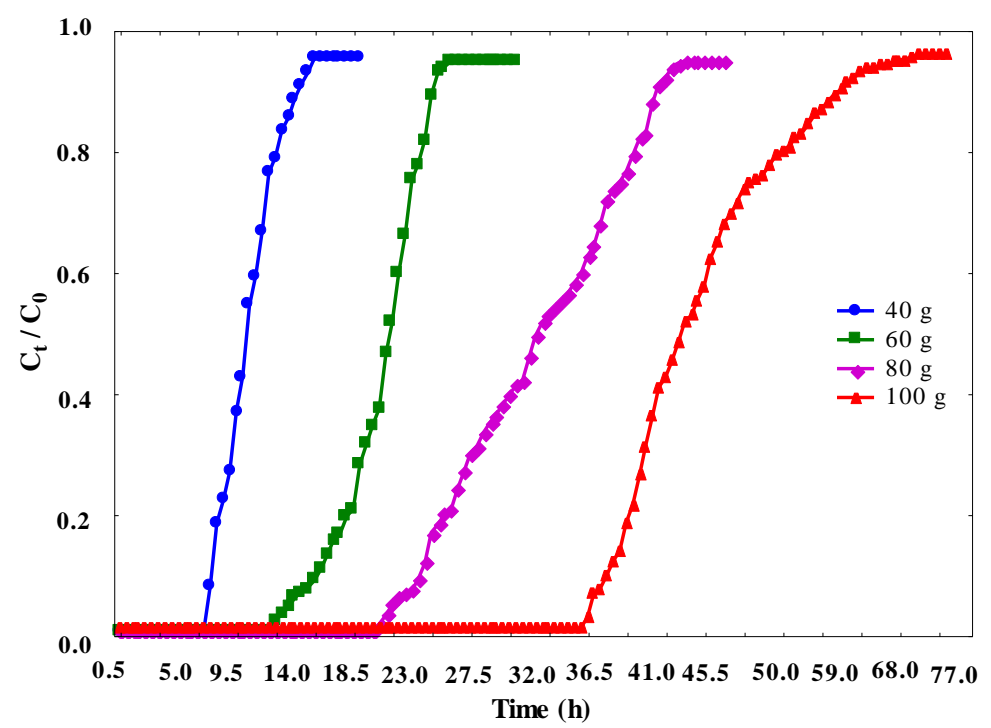

Figure 6: Breakthrough curve for studying the influence of lichen mass on VC adsorption: $(\mathrm{D}=0.15 \mathrm{~L} / \mathrm{min}, \mathrm{Co}=10 \mathrm{mg} / \mathrm{g}, \mathrm{H}=4$ $\mathrm{cm}, \mathrm{T}=25 \mathrm{C}^{\circ}$, each point on the graph represents an average which was determined from three individuals measurements.).

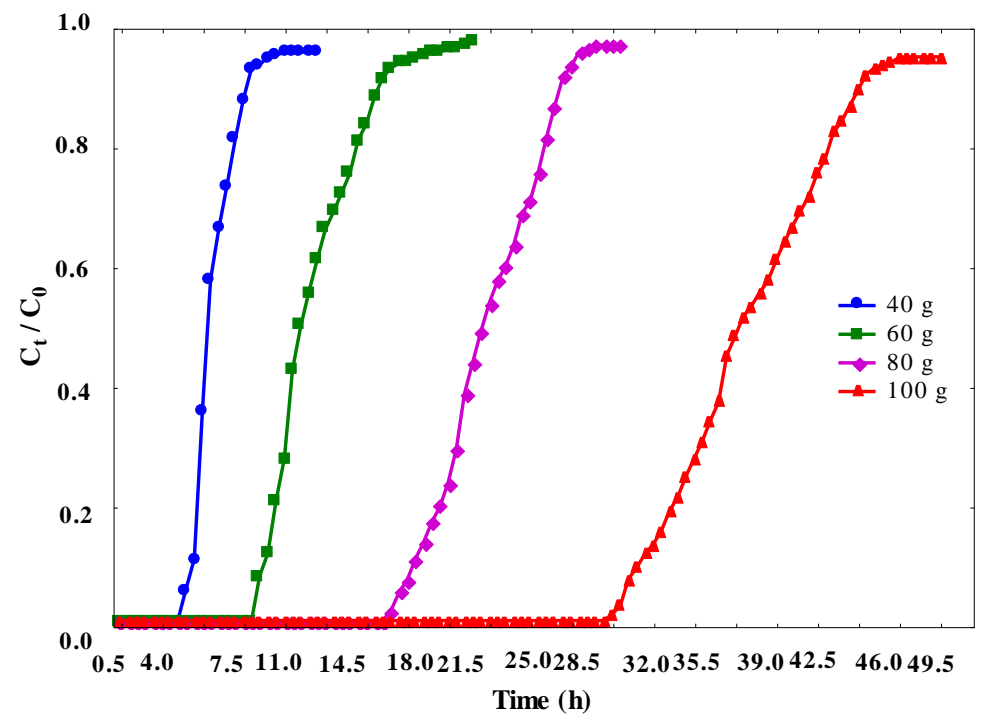

Figure 7: Breakthrough curve for studying the influence of lichen mass on MR adsorption: $(\mathrm{D}=0.15 \mathrm{~L} / \mathrm{min}, \mathrm{Co}=10 \mathrm{mg} / \mathrm{g}, \mathrm{H}=4$ $\mathrm{cm}, \mathrm{T}=25 \mathrm{C}^{\circ}$, each point on the graph represents an average which was determined from three individuals measurements.).

The experimental values obtained from the breakthrough curves for the influence of lichen quantity on VC and MR fixation are presented in the table below.

Table III: Experimental values for mass lichen effect on MR and VC and adsorption.

\begin{tabular}{|c|c|c|c|c|c|c|c|c|}
\hline & Paramètr & & & & & & & \\
\hline dyes & $\begin{array}{l}\text { Flow rate } \\
\mathrm{D}(\mathrm{L} / \mathrm{min})\end{array}$ & $\begin{array}{l}\text { Concentration } \\
(\mathrm{mg} / \mathrm{L})\end{array}$ & Co & $\begin{array}{l}\text { Mass } \\
\mathrm{m}(\mathrm{g})\end{array}$ & $\begin{array}{l}\text { Residence Time } \\
\text { (h) }\end{array}$ & $\begin{array}{l}\text { Time of } \\
\text { saturation }(\mathrm{h})\end{array}$ & $\begin{array}{l}\text { adsorbed } \\
(\mathrm{mg} / \mathrm{g})\end{array}$ & Quantity \\
\hline \multirow{4}{*}{$\mathrm{VC}$} & \multirow{4}{*}{0.07} & \multirow{4}{*}{10} & & 40 & 7 & 12 & 11.4 & \\
\hline & & & & 60 & 13 & 22.5 & 14.27 & \\
\hline & & & & 80 & 20.5 & 36 & 17.12 & \\
\hline & & & & 100 & 36.5 & 56 & 21.26 & \\
\hline \multirow{4}{*}{ MR } & \multirow{4}{*}{0.07} & \multirow{4}{*}{10} & & 40 & 4.5 & 7.5 & 7.20 & \\
\hline & & & & 60 & 9.5 & 14 & 8.87 & \\
\hline & & & & 80 & 17.5 & 22.5 & 12.16 & \\
\hline & & & & 100 & 30.5 & 45.5 & 17.33 & \\
\hline
\end{tabular}


From these results, the quantities of the two adsorbed dyes increase with the mass or height of the filter bed. Indeed, the increase in lichen mass from 20 to $100 \mathrm{~g}$ in steps of 20 leads to a rise in the quantity of adsorbed dye from $11.4 \mathrm{~g}$ to $21.26 \mathrm{mg} / \mathrm{g}$ for the $\mathrm{VC}$ and from 7.2 to $17.33 \mathrm{mg} / \mathrm{g}$ for MR (Table III). This result is due to the increase in sorption binding sites due to a larger available surface area. Table III also shows that the penetration time varies significantly with the height of the bed. By increasing the height of the bed, the solution had more time to come into contact with the lichen, resulting in higher removal efficiency of VC and MR. The residence times of the MR and the VC respectively increased from $7 \mathrm{~h}$ to $36 \mathrm{~h} 30 \mathrm{~min}$ and four h $30 \mathrm{~min}$ to $30 \mathrm{~h} 30 \mathrm{~min}$ for a mass varying from 40 to $100 \mathrm{mg}$ and a bed height ranging from 1 to $8 \mathrm{~cm}$. At this same quantity of biomass, the saturation time of the adsorption bed increases from $12 \mathrm{~h}$ to $2 \mathrm{~d} 8 \mathrm{~h}$ for the VC and from $7 \mathrm{~h} 30 \mathrm{~min}$ to $1 \mathrm{~d} 21 \mathrm{~h} 30 \mathrm{~min}$ for the RM. Soto et al. (2017) also found in their batch and fixed column studies on the adsorption of phenol contained in wine vinasses by polymer resins, that residence time increased from $19.6 \mathrm{~min}$ to $26 \mathrm{~min}$ for a flow rate of $1 \mathrm{ml} / \mathrm{min}$ and a bed height varying from 10 to $20 \mathrm{~cm}$.

\subsection{Dye concentration effect}

The study of the concentration effect of VC and MR dyes showed that the adsorption capacity increases with increasing initial dye concentration.

The breakthrough curves for studying the influence of concentrations are shown in Figure 8 and Figure 9.

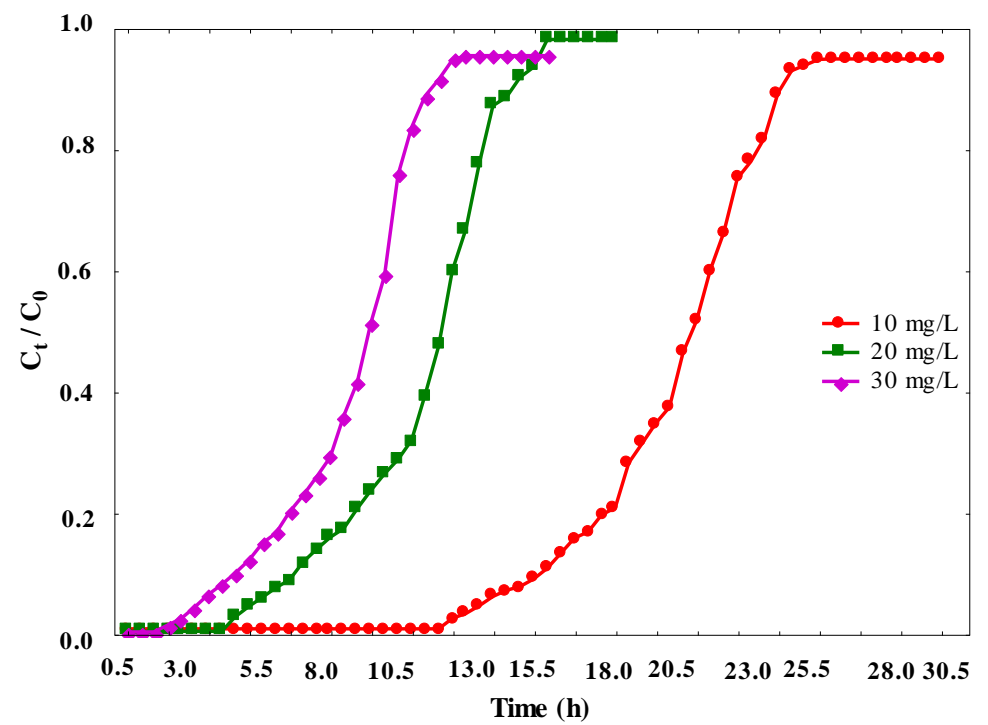

Figure 8: Breakthrough curve for studying the influence of $\mathrm{VC}$ concentration: $\left(\mathrm{D}=0.07 \mathrm{~L} / \mathrm{min}, \mathrm{m}=60 \mathrm{~g}, \mathrm{~T}=25 \mathrm{C}^{\circ}\right.$, each point on the graph represents an average which was determined from three individuals measurements.).

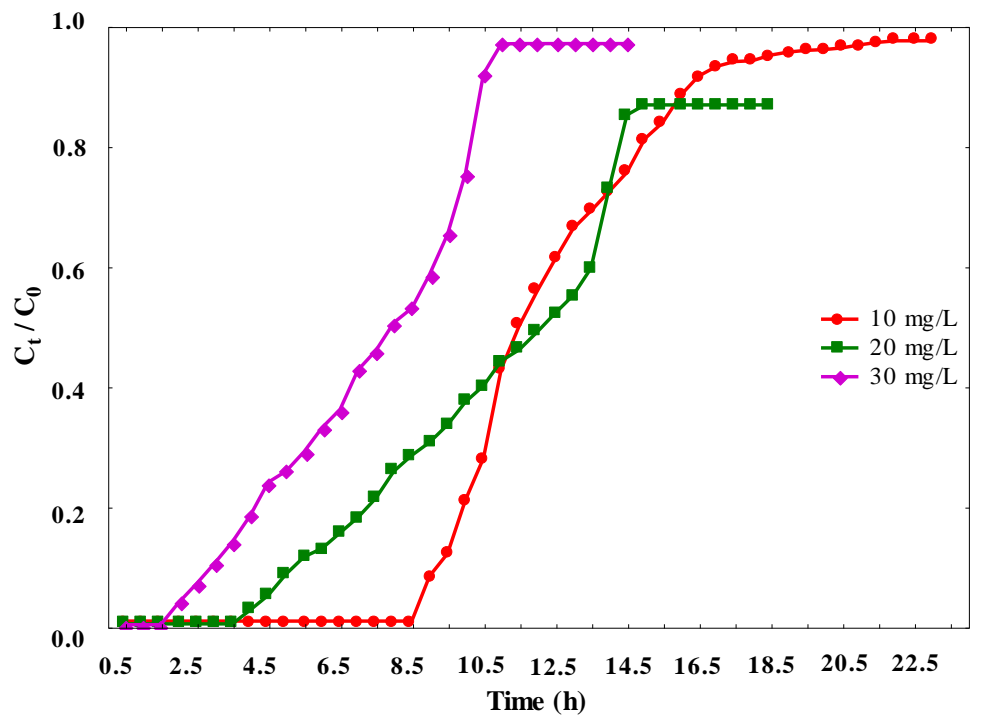

Figure 9: Breakthrough curve for the study of the influence of $\mathrm{MR}$ concentration: $\left(\mathrm{D}=0.07 \mathrm{~L} / \mathrm{min}, \mathrm{m}=60 \mathrm{~g}, \mathrm{~T}=25 \mathrm{C}^{\circ}\right.$, each point on the graph represents an average which was determined from three individuals measurements.).

Table IV: Experimental values for the initial dye concentration effect MR and VC adsorption. 
Citation: Kouassi Kouadio Dobi-Brice, et al., Column adsorption of Violet Crystal and Methyl Red by deactivated lichen Parmotrema dilatatum. Australian Journal of Basic and Applied Sciences, 13(5): 26-34. DOI: 10.22587/ajbas.2019.13.5.3

\begin{tabular}{|c|c|c|c|c|c|c|}
\hline & Paran & & & & & \\
\hline dyes & $\begin{array}{l}\text { Mass } \\
\mathrm{m}(\mathrm{g})\end{array}$ & $\begin{array}{l}\text { Flow Rate } \\
\mathrm{D}(\mathrm{L} / \mathrm{min})\end{array}$ & $\begin{array}{l}\text { Concentration Co } \\
(\mathrm{mg} / \mathrm{L})\end{array}$ & $\begin{array}{l}\text { Time of } \\
\text { residence }(h)\end{array}$ & $\begin{array}{l}\text { Time of saturation } \\
\text { (h) }\end{array}$ & $\begin{array}{l}\text { adsorbed } \\
\text { Quantity (mg/g) }\end{array}$ \\
\hline \multirow{3}{*}{ VC } & \multirow{3}{*}{60} & \multirow{3}{*}{0.07} & 10 & 13 & 22.5 & 14.27 \\
\hline & & & 20 & 4.5 & 11 & 14.65 \\
\hline & & & 30 & 2 & 9 & 18.3 \\
\hline \multirow{3}{*}{ MR } & \multirow{3}{*}{60} & \multirow{3}{*}{0.07} & 10 & 9.5 & 14 & 8.87 \\
\hline & & & 20 & 4 & 11 & 14.73 \\
\hline & & & 30 & 2 & 7.5 & 15.25 \\
\hline
\end{tabular}

Table IV show that the residence time and saturation time decrease with an increase in the concentration of each dye. The obtained residence times are $13 \mathrm{~h}$, four h $30 \mathrm{~min}$ and two $\mathrm{h}$ for the $\mathrm{VC}$ and nine $\mathrm{h} 30 \mathrm{~min} ; 4 \mathrm{~h}$ and two h for the MR at initial concentrations of 10,20 and $30 \mathrm{mg} / \mathrm{L}$ respectively. The reduction in residence times and saturation at high concentration values could be explained by the improvement of the concentration gradient for the transfer of mass through the liquid film as well as the acceleration of the adsorption rate which led to early saturation of the fixed bed (Jung et al., 2017). In contrast to the evolution profile of operating times, the amount of dye fixed on lichens increases as the concentration increases. The growth of the amount of adsorbed dye is related to the concentration gradient that provides an appropriate driving force for transporting the adsorbate molecules to the adsorbent bed (Han et al., 2006).

The results of our study are consistent with those of Vieira et al., for the adsorption of azo dyes in a fixed bed column filled with chitosan-coated glass beads at different degrees of deacetylation. In this study, the dye concentration ranged from 50,100 to 150 $\mathrm{mg} / \mathrm{L}$ and the best amounts of adsorbed dyes were obtained at high initial concentrations at the column inlet (Vieira et al., 2018).

\section{CONCLUSIONS}

This study showed the possibility of eliminating Violet Crystal and Methyl Red toxic dyes by using deactivated lichen biomass in a fixed bed column. This dynamic study revealed that the column feed rate, lichen grain size, bed height, and initial dye concentration influenced both the column operating time and the amount of dye eliminated. The best dye removals are observed for low feed rates, large masses of lichens, and high concentrations of dyes. Decreasing the feed rate increases the operating time of the column. The same effect is observed for increasing the amount of biomass and reducing the size of lichen grains. On the other hand, for high concentrations of dyes (Violet Crystal and Red Methyl Red), a reduction in the operating time is observed. It would be interesting to carry out a column adsorption study with a larger number of organic pollutants and adding inorganic pollutants in order to carry out column eliminations of pollutants contained in industrial effluents in real situations.

\section{BIBLIOGRAPHICAL REFERENCES}

Adrián, B.; D.I. Mendoza-Castillo and H.E. Reynel-Ávila, 2017. Adsorption Processes for Water Treatment and Purification, Springer. ed. Springer International Publishing, México. doi.org/10.1007/978-3-319-58136-1

Arami, M., N. Y. Limaee, N. M. Mahmoodi and N. S. Tabrizi, 2005. Removal of dyes from colored textile wastewater by orange peel adsorbent: Equilibrium and kinetic studies. J. Colloid Interface Sci. 288, 371-376. doi.org/10.1016/J.JCIS.2005.03.020

Aurélien Desaunay, 2011. Etude et modélisation de la biosorption des métaux par les bactéries. Application au transfert du cadmium et du zinc, seuls ou en mélange, par Escherichia coli et Cupriavidus metallidurans en colonnes de sable d'Hostun. Université de Grenoble.

Auset, M. and A. A. Keller, 2006. Pore-scale visualization of colloid straining and filtration in saturated porous media using micromodels. Water Resour. Res. 42. doi.org/10.1029/2005WR004639

Baysal, M., K. Bilge, B. Y1lmaz and M. Papila, 2018. Preparation of high surface area activated carbon from waste-biomass of sunflower piths: Kinetics and equilibrium studies on the dye removal. J. Environ. Chem. Eng. 6, $1702-1713$. doi.org/10.1016/J.JECE.2018.02.020

Bhuiyan, M.A.R., A. Islam, A. Ali and M. N. Islam, 2017. Color and chemical constitution of natural dye henna (Lawsonia inermis L) and its application in the coloration of textiles. J. Clean. Prod. 167, 14-22. doi.org/10.1016/J.JCLEPRO.2017.08.142

Croce, R., F. Cinà, A. Lombardo, G. Crispeyn, C.I. Cappelli, M. Vian, S. Maiorana, E. Benfenati and D. Baderna, 2017. Aquatic toxicity of several textile dye formulations: Acute and chronic assays with Daphnia magna and Raphidocelis subcapitata. Ecotoxicol. Environ. Saf. 144, 79-87. doi.org/10.1016/J.ECOENV.2017.05.046

Dobi-brice, K.K., L. Ekou, T. Ekou and Y. Zoungranan, 2018a. Biosorption du Bleu de Méthylène et de l'Orange II sur le Lichen Parmotrema Dilatatum Désactivé 149, 473-482.

Dobi-brice, K.K., L. Ekou, T. Ekou and Y. Zoungranan, 2018b. Biosorption of Methylene Blue and Orange II on deactivated lichen Parmotrema dilatatum : Modeling and kinetic studies 12, 83-89. doi.org/10.22587/ajbas.2018.12.12.14 
Citation: Kouassi Kouadio Dobi-Brice, et al., Column adsorption of Violet Crystal and Methyl Red by deactivated lichen Parmotrema dilatatum. Australian Journal of Basic and Applied Sciences, 13(5): 26-34. DOI: 10.22587/ajbas.2019.13.5.3

Dulce, R.A., S. Kulandavelu, I. H. Schulman, J. Fritsch and J. M. Hare, 2017. Nitric Oxide Regulation of Cardiovascular Physiology and Pathophysiology, in: Nitric Oxide. Elsevier, pp. 313-338. doi.org/10.1016/B978-0-12-804273-1.00024-7

Dulman, V. and S. M. Cucu-Man, 2009. Sorption of some textile dyes by beech wood sawdust. J. Hazard. Mater. 162, $1457-1464$. doi.org/10.1016/J.JHAZMAT.2008.06.046

Ekou, L., Y. Zoungranan, T. Ekou and K. V. A. Kouadio, 2017. Bioaccumulation Capacity of Cu and Fe on Lichen Parmotrema Dilatatum. Eur. J. Sci. Res. 145, 346-353.

Han, R., J. Zhang, W. Zou, H. Xiao, J. Shi and H. Liu, 2006. Biosorption of copper(II) and lead(II) from aqueous solution by chaff in a fixed-bed column. J. Hazard. Mater. 133, 262-268. doi.org/10.1016/j.jhazmat.2005.10.019

Jabs, C.F.I. and H. P. Drutz, 2001. The role of intraoperative cystoscopy in prolapse and incontinence surgery. Am. J. Obstet. Gynecol. 185, 1368-1373. doi.org/10.1067/MOB.2001.119072

Jeremy, A., R. Sharon, L. Walker and M. Elimelech, 2004. Bacterial Adhesion and Transport in Porous Media: Role of the Secondary Energy Minimum. https://doi.org/10.1021/ES034887L

Jung, K.W., T. U. Jeong, J. W. Choi, K. H. Ahn and S. H. Lee, 2017. Adsorption of phosphate from aqueous solution using electrochemically modified biochar calcium-alginate beads: Batch and fixed-bed column performance. Bioresour. Technol. 244, 23-32. doi.org/10.1016/j.biortech.2017.07.133

Kannan, C., T. Sundaram and T. Palvannan, 2008. Environmentally stable adsorbent of tetrahedral silica and non-tetrahedral alumina for removal and recovery of malachite green dye from aqueous solution. J. Hazard. Mater. 157, $137-145$. doi.org/10.1016/J.JHAZMAT.2007.12.116

Kausar, A., M. Iqbal, A. Javed, K. Aftab, Z.-H. Nazli, H.N Bhatti and S. Nouren, 2018. Dyes adsorption using clay and modified clay: A review. J. Mol. Liq. 256, 395-407. doi.org/10.1016/J.MOLLIQ.2018.02.034

Liu, J., Z. Wang, H. Li, C. Hu, P. Raymer and Q. Huang, 2018. Effect of solid state fermentation of peanut shell on its dye adsorption performance. Bioresour. Technol. 249, 307-314. doi.org/10.1016/j.biortech.2017.10.010

Lofrano, G., G. Libralato, R. Adinolfi, A. Siciliano, P. Iannece, M. Guida, M. Giugni, A. Volpi-Ghirardini and M. Carotenuto, 2016. Photocatalytic degradation of the antibiotic chloramphenicol and effluent toxicity effects. Ecotoxicol. Environ. Saf. 123, 65-71. doi.org/10.1016/J.ECOENV.2015.07.039

Mousavi, S., F. Deuber, S. Petrozzi, L. Federer, M. Aliabadi, F. Shahraki and C. Adlhart, 2018. Efficient dye adsorption by highly porous nanofiber aerogels. Colloids Surfaces A Physicochem. Eng. Asp. 547, 117-125. doi.org/10.1016/J.COLSURFA.2018.03.052

Munagapati, V.S., V. Yarramuthi, Y. Kim, K. M. Lee and D.S. Kim, 2018. Removal of anionic dyes (Reactive Black 5 and Congo Red) from aqueous solutions using Banana Peel Powder as an adsorbent. Ecotoxicol. Environ. Saf. 148, 601-607. doi.org/10.1016/J.ECOENV.2017.10.075

Nataraj, K. M. Hosamani and T. M. Aminabhavi, 2009. Nanofiltration and reverse osmosis thin film composite membrane module for the removal of dye and salts from the simulated mixtures. Desalination 249 , $12-17$. https://doi.org/10.1016/J.DESAL.2009.06.008

Nidheesh, P.V., M. Zhou and M. A. Oturan, 2018. An overview on the removal of synthetic dyes from water by electrochemical advanced oxidation processes. Chemosphere 197, 210-227. doi.org/10.1016/J.CHEMOSPHERE.2017.12.195

Nussbaum Fabian, 2008. Développe ment d'une installation de biosorption à l'échelle pilote Entwicklung einer Biosorption Pilotanlage Objectif. Haute Ecole Spécialisée de Suisse Occidentale.

Pirkarami, A. and M. E. Olya, 2017. Removal of dye from industrial wastewater with an emphasis on improving economic efficiency and degradation mechanism. J. Saudi Chem. Soc. 21, S179-S186. doi.org/10.1016/J.JSCS.2013.12.008

Sohrabi, M.R., A. Khavaran, S. Shariati and S. Shariati, 2017. Removal of Carmoisine edible dye by Fenton and photo Fenton processes using Taguchi orthogonal array design. Arab. J. Chem. 10, S3523-S3531. doi.org/10.1016/J.ARABJC.2014.02.019

Soto, M.L., A. Moure, H. Domínguez and J. C. Parajó, 2017. Batch and fixed bed column studies on phenolic adsorption from wine vinasses by polymeric resins. J. Food Eng. 209, 52-60. doi.org/10.1016/j.jfoodeng.2017.04.008

Tahir, H., M. Sultan, N. Akhtar, U. Hameed and T. Abid, 2016. Application of natural and modified sugar cane bagasse for the removal of dye from aqueous solution. J. Saudi Chem. Soc. 20, S115-S121. doi.org/10.1016/J.JSCS.2012.09.007

Vieira, M.L.G., M. S. Martinez, G. B. Santos, G. L. Dotto and L. A. A. Pinto, 2018. Azo dyes adsorption in fixed bed column packed with different deacetylation degrees chitosan coated glass beads. J. Environ. Chem. Eng. doi.org/10.1016/j.jece.2018.04.059

Wijannarong, S., S. Aroonsrimorakot, P. Thavipoke, C. Kumsopa and S. Sangjan, 2013. Removal of Reactive Dyes from Textile Dyeing Industrial Effluent by Ozonation Process. APCBEE Procedia 5, 279-282. doi.org/10.1016/J.APCBEE.2013.05.048

Zoungranan, Y., L. Ekou and K. K. Dobi-Brice, 2018. Lichen Comme Bioindicateur de la Qualité de l'air de la Ville d'Abidjan en Éléments Traces Métalliques. Eur. J. Sci. Res. 148, 501-511. 